\title{
Critical Community Practice: An Introduction to the Special Section
}

\author{
Scotney D. Evans, Natalie Kivell, Miryam Haarlammert, Krithika Malhotra, \\ and Adam Rosen
}

University of Miami

\begin{abstract}
What does it mean to practice critically in community settings? How do counselors, psychologists, social workers, community development workers, and other human service practitioners get beyond patching up the wounded and sending them back to contend with the toxic conditions in communities and society? What individual and organizational beliefs and practices would support those in need while simultaneously contributing to changing social conditions? This paper explores a model of critical community practice that highlights the theoretical underpinnings, practical applications, and organizational implications of community practice that is more radical and transformative. It also serves as an introduction to the four papers that follow in this special section.
\end{abstract}

Keywords: critical practice, critical theory, community practice, human services

\section{Introduction}

Many community-based counselors, social workers, administrators, and direct service workers struggle to find ways to combine their broader political values, understandings, and goals with daily community human service practice that both reflects and further these goals (Withorn, 1984). They understand the necessity of providing effective services to those who are suffering and also see a need to address the primary sources of this suffering. Unfortunately, what we mostly witness in human service settings is apolitical, uncritical, ameliorative practices where the original source of the problem in society is left unchanged while new programs and direct services are continuously developed and refined to treat the individuals most affected. Under this reactive, ameliorative strategy, community practitioners serve clients with the primary aim of helping people cope with the negative aspects of society (Gil, 1998; Ife, 2002; Mullaly, 1997; Prilleltensky \& Nelson, 2002). Short-term, individualistic approaches too often ignore the assets of their constituents and communities (Albee, 1986; Butcher \& Robinson, 2007; Evans et al., 2011; McCubbin, 2009; Prilleltensky, 2005; Prilleltensky \& Prilleltensky, 2003). 
Alternatively, critical or transformative community practice suggests a politicized role for human service practitioners and organizations to promote equality, solidarity, community, and social justice (Mullaly, 1997; Withorn, 1984). Under this paradigm, the role of human service organizations is to be an agent or mediator of social change through community building, organizing, systems reform, policy advocacy, and structural change. Unlike ameliorative services where the focus of intervention is the individual or family unit, transformative interventions focus on larger systems that equally affect personal, interpersonal, and collective wellness. If helping professionals and the organizations they represent are to play a role in affecting broader social change, they'll need to embrace the fundamentally political nature of their work and the radical potential for human services to be one means of achieving a more equitable and caring society (Withorn, 1984). This introductory piece and the four papers in this special section call for a larger emphasis on transformative change in community-based human services through a shared commitment to critical community practice (Butcher, Banks, Henderson, \& Robertson, 2007).

\section{A Model of Critical Community Practice}

Critical community practice (CCP) is "action based on critical theorizing, reflection, and a clear commitment to working for social justice through empowering and transformative practice" (Henderson, 2007, p. 1). It is based on the ideals of social justice, social inclusion, selfdetermination, solidarity, and collective wellness (Butcher, 2007a; Kagan \& Burton, 2001; Prilleltensky, 2001; Weil, 1996). It assumes that many community problems stem from systemic material poverty and disadvantage, social exclusion, and institutionalized oppression that are manifestations of structural inequalities and social divisions within society as a whole (Butcher, 2007b). The premise of CCP is that social transformation is possible when people have community, a voice, and equal access to valued resources. It emerges from and is a manifestation of critical social theory which extends beyond critique to critical praxis, "a form of practice in which the 'enlightenment' of actors comes to bear directly in their transformed social action" (Carr \& Kemmis, 1986, p. 145). CCP is a radical praxis (Freire, 2000) wherein action, research, and theory are complexly intertwined, and embedded in a deep understanding of the experiences of those who are marginalized, oppressed, and dispossessed. This critical praxis identifies the source of oppression in the social system and then looks to social movement building for collective solutions (Kagan \& Burton, 2001).

Barnett (1997) proposed three domains of critical practice: critical analysis, critical action, and critical reflexivity. Critical analysis comprises an ongoing critical evaluation of assumptions, values, knowledge, evidence, policies, and practices, keeping in mind multiple different perspectives. Critical action involves working toward empowerment by means of a sound skill base and recognition of social and political inequalities and structured disadvantages. Critical reflexivity implies an aware, reflective, and engaged self who recognizes the values and assumptions he/she brings to the table while also recognizing the role he/she plays in engaging with service-users and others in negotiating understanding and interventions. Alternatively, Brechin (2000) focused attention on three main attributes of critical community practitioners: 1 ) being open-minded, thoughtful, and reflective in working with individuals; 2) utilizing empowering and anti-oppressive practices that are embedded in values, assumptions, and principles of social justice; and 3) continually evaluating and reflecting on these values and 
assumptions. Butcher, et al., (2007) build on these frameworks to base their model of critical community practice on four interlocking concepts: critical consciousness, critical theorizing, critical action, and critical reflection. To better understand how these concepts might be applied to community-based practice, we will take a deeper look at each of these four components.

\section{Critical Consciousness}

Critical consciousness comprises the assumptions, value commitments, dispositions, and mindsets that necessitate practitioners to enhance their creative and analytical skills and consists of two key components: a critique of social conditions that lead to suffering and an awareness that people can change these conditions (Freire, 2000; Prilleltensky, 2011). At the organizational level, consciousness can be described as the organization's mental alertness and "awareness of itself in terms of its identity, reason for existing, and in its relations with others" (Pees, Shoop \& Ziegenfuss, 2009, p. 506). This definition presupposes that organizations have a shared identity or shared constructions of their purpose that is the outcome of collaborative meaning-making (Agashae \& Bratton, 2001; Gamson 1992) and that through a collective process they can become aware of and critique this shared identity. Organizational consciousness brings the organization into an integrated whole, united in its understanding of the world and its organizational purpose.

There is a useful connection here to Senge's (1990) notion of organizational mental models, which are "deeply held internal images of how the world works, images that limit us to familiar ways of thinking and acting" (p. 174). Senge asserts that organizations run into problems when these mental models exist below the level of awareness. Thus, organizations are conscious when there exists a deep, shared understanding of themselves, their social identity, the surrounding community, and social reality. Bringing to the foreground organizational consciousness is a necessary component for effective community practice and highlights the importance of the organization's awareness of its position and responsibility to itself, its community, and to the world (Pees et al., 2009). As stated by David Bohm (1996), "We have to share our consciousness and be able to think together, in order to do intelligently whatever is necessary" (p. 15).

But simply becoming aware of, and examining our assumptions is not critical consciousness. Critical consciousness is "becoming aware of our awareness and critiquing it" (Mezirow, 1981, p. 13). It is the critiquing of the beliefs and assumptions through the lens of social justice values, ideals, and vision that makes organizational consciousness critical. This means bringing our shared assumptions about social problems and solutions to our collective attention to better understand how we came to these understandings and theories and what conditions gave rise to them (Midgley, Munlo, \& Brown, 1998).

Social movement theorists recognize the importance of consciousness in galvanizing citizen action (Gaventa \& Cornwall, 2007). They speak of "frame alignment" as the linkage of organizational values, beliefs, interpretive orientations, and organizational activities (Snow et al., 1986). An example of critical consciousness in organizations is when groups examine and critique shared assumptions so as to understand certain social problems no longer as misfortune, but as injustice (Turner, 1969; Freire, 2000; Gramsci, 1971). CCP is grounded in an organizational consciousness that adopts an injustice frame: a mode of interpretation that espouses a commitment to social justice and defines the current state of affairs in society as 
unjust (Butcher, 2007; Gamson, 1982; Piven \& Cloward, 1977). It also requires that organizations have a shared understanding of the role of power in promoting or inhibiting wellbeing in communities. These elements of critical consciousness can be observed in organizational values, mission, vision, discourse, and theory of change (Evans et al., 2011; Kunruether \& Bartow, 2010).

The development of an organizational critical consciousness-the shared awareness of how social institutions, political structures and economic relations create and maintain conditions of oppression-enables people and organizations to better confront unjust systems and structures (Kagan \& Burton, 2001). Martín-Baró (1994) argued that if psychologists do not develop a critical consciousness they would never be able to make a meaningful contribution to the real problems of the day. The same goes for groups of helpers trying to develop a shared understanding of social conditions and wanting to make meaningful contributions through their work in community-based organizations.

\section{Critical Theorizing}

Critical theorizing is about praxis; putting forward practical models with a critical theoretical base to better understand the current situation and to suggest alternative futures and strategies for change. Theorizing is part of a human process of trying to make our actions and experiences more intelligible (Argyris \& Schon, 1974). However, too often the theories that help us make sense of community-based practice remain tacit and infrequently reflected upon, challenged, and revised based on new understandings. Mindful action by organizations requires the active participation of practitioners in joint analysis, in the articulation and formulation of frameworks, concepts, and theories undergirding their practices and in the ongoing development of these theories through continuing action and reflection (Carr \& Kemmis, 1986; Weick, 2009; Ife 1997). Barnett (1997) urges practitioners to become "practicing epistemologists" able to make sense of the world through critical frameworks and be adept at handling those frameworks in action.

Becoming practicing critical epistemologists means engaging in the active process of attempting to better understand how power dynamics in society generate and reproduce disadvantage, exclusion, and oppression in communities (Butcher, 2007b). Critical theorizing is informed by historical analysis and is the critical evaluation of knowledge, evidence, policies, power, and practice that locates the sources of oppression in the social system rather than in individual deficits and missed opportunities (Kagan \& Burton, 2001; Butcher, 2007b; Kidder \& Fine, 1986; Seidman \& Rappaport, 1986; Snow et al., 1986; Nelson, et al, 2004). It assists organizations in developing a critical consciousness and provides a perspective on how power can be used by communities to promote a more just and equal social order. (Butcher, 2007b; Sayer, 1986).

CCP means rejecting the idea that theory and practice are separate activities. Traditional community-based practice can tend to be anti-theory, habitual, customary, or mind-less (Carr \& Kemmis, 1986; Ife, 1997; Weick, 2009). "They [theory and practice] are to be understood as mutually constitutive ... [in which] neither thought nor action is pre-eminent" (Carr \& Kemmis, 1986, p. 34). What is called for is a reflexive relationship between critical theorizing and practice, or 'critical praxis', in which the informed awareness of practitioners and organizations comes to bear directly in their planned social action (Freire, 2000) (see Sonn \& Quayle, this issue). A unity of theory and practice requires the community practitioner and human service 
organization to be constantly reflecting on the nature of their practice to "gain a deeper understanding of the community, society, and social change, and to be evaluating theory in terms of practice, and practice in terms of theory" (Ife, 2002, p.229). A move from community practice to critical praxis brings social action under considered critical control, and infuses it with a commitment to social justice values (Carr \& Kemmis, 1986).

\section{Critical Action}

Critical action refers to coordinated action by organizations, practitioners, community members, and policy-makers through social movement building and collective action. It is transformative action grounded in critical consciousness and critical theorizing and engages communities to alter existing relationships of power, domination, and oppression. By contrast, ameliorative practice by HSOs focuses on caring for individuals who have already been afflicted by some psychological, physical, or social ailment while leaving the contributing system unchanged (Gil, 1998; Ife, 2002; Mullaly, 1997; Prilleltensky \& Nelson, 2002). Through transformative practice, power dynamics and oppressive systems, rather than individuals, represent the target of intervention for producing community change in communities (Rappaport, 1977; Prilleltensky \& Nelson, 2002; Evans, Hanlin, \& Prilleltensky, 2007). Speer \& Hughey (1996) suggest the concept of the "power-based community organization"; one that is characterized by working towards the development of social power to produce community change. Power-based community organizations aim to shape community conditions by altering dynamics of social power (Gutierrez, 1991; Swift and Levin, 1987).

Critical action has a strong emphasis on community organizing, collaborative strategies, grassroots leadership development, and increasing the active engagement, ownership, and power of those most affected by the social conditions under consideration. Critical action aims to "develop a critical consciousness concerning social realities, and to organize and act against destructive societal conditions that obstruct fulfillment of their needs" (Gil, 1998, p. 82). Social interventions with a critical bent strive for a more just community, seek to democratize society, and to improve access to vital services such as health care, childcare, transportation, and quality public education. Community-based organizations that practice critically, are social change organizations intimately tied to social movements that are addressing systemic and structural causes of social and economic inequalities in order to transform society for greater justice. If helpers are to promote, rather than impede social justice, they need to be connected with and accountable to social movements (Kagan et al., 2011; Chetkovich \& Kunreuther, 2006; Smith, 2007; McCarthy \& Zald, 1977). They link their community practice with social movements to be part of a wider movement for a just society. This linkage to broader social movements naturally makes collaboration a core strategy as organizations build relationships with other agencies, groups, and coalitions.

A key component of critical action in HSOs is meaningful participation by and partnership with constituents. Community-based organizations can enable participatory processes by creating structures that support community members' participation as agents of social change. Human service organizations practice critically with their constituents by acting together as part of a joint undertaking that arises out of their shared wisdom, dialogue, and understanding (Ife, 2001). Critical action is about enabling communities to use power to bring about significant change in the conditions of their lives through their own actions (Butcher, 2007b). HSOs can empower activist constituents by serving as sites for mobilization and development of 
leadership. In the process, HSOs build their own consciousness and the consciousness of their clients and constituents to better understand their circumstances in the context of larger structural factors (Chetkovich \& Kunreuther, 2006).

\section{Critical Reflection}

Dewey (1993) defines reflection on action as a behavior that involves active, persistent, and careful consideration of any belief or practice in light of the grounds that support it and the further consequences to which it leads. The process of reflection, in its most general sense, involves stepping back from and systematically reviewing the things we are doing. Freire (2000) describes the interaction between action, reflection, and learning as an iterative, interactive, and ongoing process in which reflection and action not only inform one another, but also rely on each other. Reflection without action becomes stagnation and action without reflection becomes superficial and habitual. Reflection "emancipates us from merely impulsive and routine activity... enables us to direct our actions with foresight and to plan according to ends in view of purposes of which we are aware. It enables us to know what we are about when we act" (Schon, 1983, p. 17). Reflexivity, adds the dimension of personal or shared examination of our assumptions, values, and dominant professional constructions that influence practice and how those thoughts have been shaped (Butcher, 2007a).

Reflection becomes critical reflection when we acknowledge the historical, social, and political aspects of experience. For critical theorists, reflection has no meaning unless it is accompanied by awareness of power relationships and sociopolitical realities (Reynolds, 1998). The questioning of assumptions and consideration of relationships of power within social and political contexts is the key difference between critical reflection and other forms of reflection (Carson \& Fisher, 2006). Critically reflective practitioners actively reflect upon their work and upon the social and political context in which their work is embedded (Schon, 1983; Dokecki, 1992; Newbrough, 1995). Critically reflective practice involves (1) asking searching questions to get beneath the surface of the situations we encounter to ensure that we have more than a superficial grasp (Murray \& Kujundzic, 2005); and (2) taking account of wider social and political processes that disadvantage marginalized groups of people and reinforce patterns of discrimination and oppression (Mullaly, 2002).

Critical reflection does not occur in private. It occurs in the midst of practice and in the presence of others (Raelin, 2001). Wenger's (1998) social theory of learning views learning as a fundamentally social phenomenon with individuals reflecting on meaning, identity, and practice in the context of a supportive community. In HSOs, this public critical reflection through open dialogue is a key component of organizational learning and critical practice. Individual and organizational critical consciousness is not attainable through individual self-reflection; it requires sharing and exploring experiences with others, through conversations, and what Mercer (2000) calls "interthinking" (thinking together) (Butcher, 2007). "Public reflection" can increase learning at all levels of experience and open individual minds and organizational schemas to data that run contrary to currently held comfortable stances (Raelin, 2001; Senge, 1990). Organizational members can make explicit the shared assumptions and models in use and they are willing to expose them to critical examination (Butcher, 2007). Dialogue and reflection on practice in the company of colleagues inside and outside of the organization helps submit thinking and practice to the critical gaze of others (Weil, Roman, \& Flood, 1997). 


\section{Critical Community Practice in Action}

The sections above, present underlying tenets and guiding theories for CCP, however, manifestations of this approach in the real world are diverse and wide-ranging. In day-to-day practice, CCP involves providing care for those in need in tandem with social change efforts to democratize society and transform the systemic roots of injustice and oppression (Gil, 1998; Mullaly, 1997; Withorn, 1984). As such, CCP is best understood as an orientation towards social and psychological knowledge and practice, rather than a single theory or set of concepts (Hook, Mkhize, Kiguwa, \& Collins, 2004). The core principles of this orientation, which include a focus on social justice, empowerment, and transforming social systems, can be applied across multiple disciplines in countless ways. Largely dependent on the specific context, this might entail the adaptation of existing practices or interventions to align with the core components of CCP or the creation of new methods for generating knowledge and effecting social change. In counseling and psychotherapy for example, in contrast to the historically apolitical and individual focus of the dominant theoretical models typically used (Prilleltensky, 1989), a CCP approach reflects a broader understanding of the factors that influence well-being and possible targets of intervention. Critical counseling practice pays particular attention to how clinical problems are rooted in unjust life conditions. Counselors can help clients reframe their problems in terms of structural conditions and consequences. They help shift the discourse from a medical model framing of diagnosis and therapy, to a critical language of oppression and empowerment. CCP in applied settings, therefore, requires an expansion of professional roles to include both micro- and macro-levels of intervention. Highlighting efforts of community groups across a variety of settings can help concretize the principles of CCP and provide professionals with practical examples to emulate in their own work.

Of course, the ideas presented here are not altogether new. Across the applied arenas of human services, counselors, psychologists, and social workers have been incorporating many of the principles of CCP in their daily work in communities. Other theorists and disciplines have conceptualized this critical approach to practice as structural or radical social work (Carniol, 2000; Fook, 2012; Mullaly, 2002; 1997; Pease \& Fook, 1999), just practice (Finn \& Jacobson, 2008; 2003), just therapy (Waldergrave, 1990), feminist therapy (Enns, 2004), social justice counseling (Aldarondo, 2007; Toporek et al., 2006; Vera and Speight, 2003), critical community psychology (Fryer, Duckett, \& Pratt, 2004; Kagan et al., 2011; Prilleltensky \& Nelson, 2002), and community development (Ife, 2002) to name just a few. A model of critical community practice provides an overarching framework through which these ideas can be organized.

In addition to providing new ways of approaching applied professional human service contexts, principles of CCP radically alter conceptions of the community research endeavor. For instance, participatory action research (PAR) is a research philosophy that exemplifies the empowering and transformative work with which CCP is concerned. PAR shifts the paradigm from conducting research on people and instead attempts to generate new psychological knowledge with people (Fals Borda, 2006; Montero, 2000; Prilleltensky, 2002). As the name implies, participation is a central feature of a process whereby key stakeholders are enlisted as "co-researchers", who are involved in all aspects of the research. The other core component of PAR is that these projects are explicit in their intention to utilize the co-created knowledge by taking some form of social action to improve the lives of the participants. This method is often described as a means for giving voice to the experiences and concerns of individuals from marginalized groups (Kirby \& 
McKenna, 1989). Additionally, it represents a way for researchers and oppressed people to join together and work towards social change (Hall, 1993).

\section{The Papers in this Special Section}

The four papers that follow in this special section provide a broad context for understanding the application of CCP. In "Community Cultural Development for Social Change: Developing Critical Praxis", Christopher Sonn and Amy Quayle focus on the critical community arts praxis of a community cultural development agency, Community Arts Network Western Australia (CAN WA). This agency is co-located in three rural communities in Western Australia, where there are relatively large Aboriginal populations. Sonn and Quayle make the case for community arts practice as a meaningful way of engaging in critical praxis that empowers community members and encourages creativity. The authors argue that community arts engagements enable participants to create visual representations of the impact of oppressive ideologies and practices. In this vein, community arts practice moves away from prescriptive modes of community development and opens other paths for knowing, learning, action, and reflection by acting as a visual and cooperative vehicle for leading the way to transformative and emancipatory change.

Karie Peralta and John Murphy's paper "Engaging a Community-based Perspective: The Problems of and Prospects for a Grassroots Endeavor in the Dominican Republic", analyzes the inconsistencies present in a grassroots, non-profit organization in the Dominican Republic, which uses traditional structures of hierarchy and takes on a reactive approach when addressing community concerns and problems. The aim of their research was to evaluate the potential for improving volunteer participation and collaboration in their summer program, focusing on the local volunteers' ability to engage and participate within the traditional structure. The authors make the case for pursuing a community-based approach as a critical and effective alternative to the traditional approach in order to proactively realize more just, critical, and sustainable community engagement practices. By following a community-based approach, practices are neither imposed nor imported, and rather are aligned with the community's specific interests and values through the active co-creation of all involved and the critical reflection of processes.

Highlighting and critiquing the effects of neoliberalism on community practice is important to our critical theorizing about practice in the broader political and economic context. In "Critiquing and Analyzing the Effects of Neoliberalism on Community Organizing: Implications and Recommendations for Practitioners and Educators", Shane Brady, Andrew Schoeneman, and Jason Sawyer deconstruct the effects of neoliberalism on the field of community organizing and provide tangible real world recommendations. The authors analyze three neoliberal trends through a Critical-Foucauldian framework: 1) the promotion and influence of evidence-based practices on the work of community organizing; 2) the lack of emphasis on and misrepresentation of social movements in community organizing practice and education; and finally, 3) the professionalization of community organizing. Their tangible and deeply reflective analysis provides clear direction for professional and non-professional community organizers to engage in critical community practice. Their push to return to a more radical and critical form of community organizing through their critical theorizing links the content and purpose of this piece closely with the theme of this special section. 
Lastly, in "Observing Privilege: Examining Race, Class and Gender in Health and Human Service Organizations", Leslie Collins and Sandra Barnes studied the relationship among race, class, and gender on the processes of power and privileges in health and human service organizations. In contrast to the other papers in this special section, this paper zeros in on organizational structures and practices as they connect to critical community practice. Using bivariate and multivariate analyses on data accessed from five organizations, the authors empirically tested the impact of societal ideologies (e.g., racism, classism and sexism) on employees' perceptions of their work environment in terms of agency (participation in decision making), relationships (collaborative and empowering environments), and access to learning opportunities. The authors argue that this exploratory study has the potential to open space for critical reflection and action aimed at deconstructing privilege and disrupting processes, shaped by Eurocentric, middle class, and sexist values within organizations. Their findings highlight race as a key predictor of relationships and access to learning opportunities, and demonstrate the imminent need for organizations to engage in critical community practices aimed at dismantling traditional organizational systems by supporting the development of culturally sensitive spaces.

\section{Conclusion}

As we reflect on the model of critical community practice as presented here and in the papers in this special section, a more radical picture of helping begins to emerge. Helping is supporting, serving, and raising the awareness of individuals in need; helping is also targeting changes in the norms, policies, and practices of institutions, social systems, and the broader political economy. Helping is also about creating the conditions that enable community members to participate as agents of social change rather than only recipients of services (Evans, 2012). Critical community practice requires human service organizations and practitioners to participate in ongoing reflections on their ideologies and practices, to use their practical experiences to inform a shared understanding of the community, society, and social change, and to use practice as a measure to evaluate theory and vice-versa (Evans, 2013). Critical community practice is a goal to aim for in community organizations rather than a simple prescription for all. It is a vision of what community practice in social work, counseling, psychology, and community development could be, in terms of its potential to contribute to a more just and equitable world.

\section{Contact Information:}

Scotney D. Evans

School of Education \& Human Development

University of Miami

5202 University Drive, MB 312

Coral Gables, FL 33146

Email: s.evans4@miami.edu 


\section{References}

Agashae, Z., \& Bratton, J. (2001). Leader-follower dynamics: Developing a learning environment. Journal of Workplace Learning, 13(3/4), 89-102.

Albee, G. W. (1986). Toward a just society: Lessons from observations on the primary prevention of psychopathology. American Psychologist, 41(8), 891-898. doi:10.1037/0003-066X.41.8.891

Aldarondo, E. (2007). Advancing social justice through clinical practice. London: Routledge.

Argyris C., \& Schön D. (1974). Theory in practice. San Francisco: Jossey Bass.

Barnett, R. (1997). Higher education: A critical business. Buckingham, UK: Open University Press.

Bohm, D. (1996). On dialogue. in Nichol, L. (Ed.), The change handbook: Group methods for shaping the future. London: Routledge.

Brechin, A. (2000). Introducing critical practice. In A. Brechin, H. Brown, \& M. Eby (Eds.), Critical practice in health and social care (pp. 25-47). London: Open University Press. Retrieved from http://openlearn.open.ac.uk/file.php/3924/!via/oucontent/course/302/k315_1_001.pdf

Butcher, H. (2007a). Power and empowerment: The foundations of critical community practice. In H. Butcher, S. Banks, P. Henderson, \& J. Robertson (Eds.) Critical community practice, (pp 17-32). Bristol, UK: Policy Press.

Butcher, H. (2007b). What is critical community practice? Cases studies and analysis. In $\mathrm{H}$. Butcher, S. Banks, P. Henderson, \& J. Robertson (Eds.) Critical community practice, (pp 33-49). Bristol, UK: Policy Press.

Butcher, H., Banks, S., Henderson, P., \& Robertson, J. (2007). Critical community practice. Bristol, UK: Policy Press

Butcher, H. \& Robinson, J. (2007). Critical community practice: Organizational leadership and management. In H. Butcher, S. Banks, P. Henderson, \& J. Robertson (Eds.), Critical community practice (pp. 97-115). Bristol, UK: Policy Press.

Carniol, B. (2010). Case critical: Social services \& social justice in Canada (6th ed.). Toronto: Between The Lines.

Carr, W., \& Kemmis, S. (1986). Becoming critical: Education knowledge and action research. Philadelphia, PA: The Falmer Press.

Carson, L., Fisher, K. (2006). Raising the bar on criticality: students' critical reflection in an internship. Journal of Management Education, 30(5), 700-723.

Chetkovich, C., \& Kunreuther, F. (2006). From the ground up: Grassroots organizations making social change. Ithaca, NY: ILR Press. 
Dewey, J. (1933). How we think: A restatement of the relation of reflective thinking to the educative process (First Edition.). Lexington, MA: D.C. Heath.

Dokecki, P. (1992). On knowing the community of caring persons: A methodological basis for the reflective-generative practice of community psychology. Journal of Community Psychology, 20, 26-35.

Enns, C. Z. (1997). Feminist theories and feminist psychotherapies: Origins, themes, and variations (Vol. xiii). Binghamton, NY: Harrington Park Press/The Haworth Press.

Evans, S. D. (2013). The critical friend: Promoting critical community praxis. Manuscript submitted for publication.

Evans, S. D. (2012). From amelioration to transformation in human services: Towards critical practice. Saarbrücken, Germany: LAP LAMBERT Academic Publishing.

Evans, S. D., Prilleltensky, O., McKenzie, A., Prilleltensky, I., Nogueras, D., Huggins, C., \& Mescia, N. (2011). Promoting strengths, prevention, empowerment, and community change through organizational development: Lessons for research, theory, and practice. Journal Of Prevention \& Intervention In The Community, 39(1), 50-64. doi:10.1080/10852352.2011.530166

Evans, S. D., Hanlin, C. E., \& Prilleltensky, I. (2007). Blending ameliorative and transformative approaches in human service organizations: A case study. Journal of Community Psychology, 35(3), 329-346.

Fals Borda, O. (2001) Participatory (Action) Research in social theory: Origins and challenges. In P. Reason \& H. Bradbury (Eds.) Handbook of action research. Participative inquiry and practice (pp. 27-37). London: Sage.

Finn, J. L., \& Jacobson, M. (2008). Just practice: A social justice approach to social work. Peosta, IA: Eddie Bowers.

Finn, J. L., \& Jacobson, M. (2003). Just practice. Journal of Social Work Education, 39(1), 5778. doi:10.1080/10437797.2003.10779119

Fook, J. (2012). Social work: A critical approach to practice (Second Edition edition.). Thousand Oaks, CA: SAGE Publications Ltd.

Freire, P. (2000). Pedagogy of the oppressed (30th Anniversary Edition.). New York: Continuum.

Fryer, D., Duckett, P., \& Pratt, R. (2004). Critical community psychology: what, why and how? Clinical Psychology, 38, 39-43.

Gamson, W.A. (1992). Talking politics. New York: Cambridge University Press.

Gaventa, J., \& Cornwall, A. (2008). Power and knowledge. In P. Reason \& H. Bradbury (Eds.), Handbook of action research: Participative inquiry and practice (2nd ed., pp. 172-189). Thousand Oaks, CA: SAGE Publications, Inc. 
Gil, D. G. (1998). Confronting injustice and oppression: Concepts and strategies for social workers. New York: Columbia University Press.

Gramsci, A. (1971). Selections from the prison notebooks. London: Lawrence and Wishart.

Gutierrez, L. M. (1991). Working with women of color: an empowerment perspective. Social Work, 35, 149-153.

Hall, B. (1993). Introduction. In P. Park, M. Brydon-Miller, B. Hall and T. Jackson (eds), Voices of change: Participatory research in the United States and Canada (xiv-xii). Westport, CT: Bergen and Garvey.

Henderson, P. (2007). Introduction. In Butcher, H., Banks, S., Henderson, P., \& Robertson, J. (Eds.). Critical community practice (1-15). Bristol, UK: Policy Press.

Hook, D., Mkhize, N., Kiguwa, P., \& Collins, A. (2004). Critical psychology. Lansdowne: UCT Press.

Ife, J. W. (2002). Community development: Community-based alternatives in an age of globalization. Frenchs Forest, NSW: Pearson Education.

Ife, J. (1997). Rethinking social work: Towards critical practice. South Melbourne, Australia: Longman.

Kagan, C., Burton, M., Duckett, P., Lawthom, R., \& Siddiquee, A. (2011). Critical Community Psychology. West Sussex, UK: Wiley-Blackwell.

Kagan, C., \& Burton, M. (2001). Critical community psychology praxis for the 21st century. Manchester Metropolitan University, Interpersonal and Organisational Development Research Group.

Kirby, S.L. and McKenna, K. (1989). Experience, research, social change: Methods from the margins. Toronto: Garamond Press.

Kunruether, F., \& Bartow, F. (2010). Catalysts for change: How California nonprofits can deliver direct services and transform communities (Part 1). Building Movement Project. Retrieved from http://buildingmovement.org/pdf/catalysts_part_one.pdf

McCubbin, L. (2009). Intersecting multiple identities: The case of Lehua. In M. E. Gallardo, B. W. McNeill (Eds.), Intersections of multiple identities: A casebook of evidence-based practices with diverse populations (pp. 85-111). New York: Routledge/Taylor \& Francis Group.

Martín-Baró, I. (1994). Writings for a liberation psychology. Cambridge, MA: Harvard University Press.

McCarthy, J. D., \& M. N. Zald. (1977). Resource mobilization and social movements: A partial theory. American Journal of Sociology, 82, 1212-1241.

Mercer, N. (2000). Words and minds: How we use language to think together. London: Routledge. 
Mezirow, J. (1981). A critical theory of adult learning and education. Adult Education Quarterly, 32(1), 3-24. doi:10.1177/074171368103200101

Midgley, G., Munlo, I., \& Brown, M. (1998). The theory and practice of boundary critique: Developing housing services for older people. The Journal of the Operational Research Society, 49(5), 467-478. doi:10.2307/3009885

Montero, M. (2000) Participation in participatory action-research. Annual Review of Critical Psychology, 2, 131-144.

Mullaly, B. (2002). Challenging oppression: A critical social work approach. New York: Oxford University Press.

Mullaly, R. P. (1997). Structural social work: Ideology, theory, and practice (2nd ed.). New York: Oxford University Press.

Murray, M., \& Kujundzic, N. (2005). Critical reflection: A textbook for critical thinking. Montreal: McGill-Queen's University Press.

Newbrough, J. R. (1995). Toward community: A third position. American Journal of Community Psychology, 23(1), 9-37. doi:10.1007/BF02506921

Pease, B. and Fook, J. (eds) (1999). Transforming social work practice: Postmodern critical perspectives. Sydney: Allen and Unwin.

Pees, R. C., Shoop, G. H., \& Ziegenfuss, J. T. (2009). Organizational consciousness. Journal of Health Organization and Management, 23(5), 505-521.

Piven, F. F., \& Cloward, R. (1978). Poor people's movements: Why they succeed, how they fail. New York: Vintage Books.

Prilleltensky, I. (2011). Wellness as fairness. Paper presented as Distinguished Contribution to Theory and Research at the Biennial Conference of the Society for Community Research and Action, Division 27 of the American Psychological Association, Chicago, IL.

Prilleltensky, I. (2005). Promoting well-being: Time for a paradigm shift in health and human services. Scandinavian Journal Of Public Health, 33(5), 53-60.

Prilleltensky, I. (2001). Value-based praxis in community psychology: Moving toward social justice and social action. American Journal Of Community Psychology, 29(5), 747.

Prilleltensky, I. (1989). Psychology and the status quo. American Psychologist, 44(5), 795-802. doi:10.1037/0003-066X.44.5.795

Prilleltensky, I., \& Nelson, G. (2002). Doing psychology critically: Making a difference in diverse settings. New York, NY: Palgrave Macmillan.

Prilleltensky, I., \& Prilleltensky, O. (2003). Towards a critical health psychology practice. Journal of Health Psychology, 8(2), 197-210. 
Raelin, J. A. (2001). Public reflection as the basis of learning. Management Learning, 32(1), 1130.

Rappaport, J. (1977). Community psychology: Values, research and action. New York: Holt, Rinehart \& Winston.

Sayer, J. (1986). Ideology: The bridge between theory and practice. Community Development Journal, 21(4), 294-303. doi:10.1093/cdj/21.4.294

Schon, D. A. (1983). The reflective practitioner: How professionals think in action. New York: Basic Books.

Senge, P. M. (1990). The fifth discipline: the art and practice of the learning organization (1st ed.). New York: Doubleday.

Smith, A. (2007). Introduction: The revolution will not be funded. In INCITE! Women of Color Against Violence (Eds.), The revolution will not be funded: Beyond the non-profit industrial complex (pp. 1-18). Cambridge, MA: South End Press.

Snow, D. A., Rochford, E. B., Worden, S. K., \& Benford, R. D. (1986). Frame alignment processes, micromobilization, and movement participation. American Sociological Review, 51(4), 464-481. doi:10.2307/2095581

Speer, P. W., \& Hughey, J. (1996). Mechanisms of empowerment: Psychological processes for members of power-based community organizations. Journal of Community \& Applied Social Psychology, 6(3), 177-187.

Swift, C. \& Levin, G. (1987). Empowerment: an emerging mental health technology. Journal of Primary Prevention, 8, 71-94.

Toporek, R.L., Gerstein, L.H., Fouad, N.A., Roysircar, G. S., \& Israel, T. (2006). Handbook for social justice in counseling psychology: Leadership, vision, \& action. Thousand Oaks, CA: Sage.

Turner, R. H. (1969). The theme of contemporary social movements. The British Journal of Sociology, 20(4), 390-405. doi:10.2307/588924

Vera, E. M., \& Speight, S. L. (2003). Multicultural competence, social justice, and counseling psychology: Expanding our roles. The Counseling Psychologist, 31(3), 253-272. doi:10.1177/0011000003031003001

Waldegrave C.T. (1990). Just therapy. Dulwich Centre Newsletter, No. 1, 5-46, Adelaide, Australia.

Weick, K. E. (2009). Making sense of the organization (Vol. 2). West Sussex: Wiley \& Sons.

Weil, M. (1996). Community building: Building community practice. Social Work, 41(5), 481499.

Weil, S., Romm, N., \& Flood, R. (1997) Critical reflexivity: Multi-dimensional conversations. Northampton: The SOLAR Centre, Nene University College. 
Volume 6, Number 1, Summer 2014

Wenger, E. (1998). Communities of practice: Learning, meaning, and identity. Cambridge, UK: Cambridge University Press.

Withorn, A. (1984). Serving the people: Social services and social change. New York: Columbia University Press. 